\title{
SIKAP MASYARAKAT SEKITAR KAWASAN MARUNDA TERHADAP RESTORASI EKOLOGI HUTAN MANGROVE DI KELURAHAN MARUNDA, KECAMATAN CILINCING, JAKARTA UTARA
}

\author{
MARUNDA AREA PEOPLE'S ATTITUDES AGAINST \\ ECOLOGICAL RESTORATION OF MANGROVE FOREST IN \\ MARUNDA VILLAGE, CILINCING SUB-DISTRICT, NORTH \\ JAKARTA, DKI JAKARTA
}

\author{
Nesmi Puspitasari, Eny Lestari, Emi Widiyanti \\ Program Studi Penyuluhan dan Komunikasi Pertanian, Fakultas Pertanian, \\ Universitas Sebelas Maret \\ Jl.Ir.Sutami No.36 A Kentingan Surakarta 57126 Telp./Fax (0271) 637457 \\ Email: nesmi110195@gmail.com/Telp.087776072595
}

\begin{abstract}
This research aims to determine the factors that shape the attitudes of the community, to know the attitude of the community, to analyze the relationship between the factors that shape the public attitudes, and to analyze the differences of people's attitudes toward the economic impacts of the people who live close to the restoration site with the people who live far from Location of restoration of ecological restoration of mangrove forest. The location of the study was determined purposively. The sampling method used is proportional random sampling, with sample number 60 Marunda Pulo community. The result of the research shows that: (1) There is a significant relationship between the attitude of the community with the influence of others who are considered important. While there is a non-significant relationship between the attitude of the community towards age, type of work, formal education, non-formal education, and mass media exposure. (2) There is a significant difference between the attitude of the people whose location is $\mathbf{4 0 0}$ meters away from the coast with the attitude of the people whose residence is more than 400 meters from the beach.
\end{abstract}

Keywords:Attitude, Ecological Restoration, Mangrove Forest, U Mann Whitney

Abstrak

Penelitian ini bertujuan untuk mengetahui faktor-faktor yang membentuk sikap masyarakat, mengetahui sikap masyarakat, menganalisis hubungan antara faktor-faktor pembentuk sikap masyarakat, serta menganalisis perbedaan sikap masyarakat terhadap dampak ekonomi masyarakat yang tinggal dekat dengan lokasi restorasi dengan masyarakat yang tinggal jauh dari lokasi restorasi terhadap upaya restorasi ekologi hutan mangrove. Lokasi penelitian ditentukan secara purposive. Metode pengambilan sampel yang digunakan adalah 


\section{Jurnal Agritexts Volume 41 Nomer 2 Oktober 2017}

proportional random sampling, dengan jumlah sampel 60 masyarakat Marunda Pulo. Hasil penelitian menunjukkan bahwa: (1) Terdapat hubungan yang signifikan antara sikap masyarakat dengan pengaruh orang lain yang dianggap penting. Sedangkan terdapat hubungan yang tidak signifikan antara sikap masyarakat terhadap umur, jenis pekerjaan, pendidikan formal, pendidikan non formal, dan keterpaan media massa. (2) Terdapat perbedaan yang signifikan antara sikap masyarakat yang lokasi tempat tinggalnya berada 400 meter dari pinggir pantai dengan sikap masyarakat yang tempat tinggalnya lebih dari 400 meter dari pinggir pantai.

Kata Kunci: Hutan Mangrove, Restorasi Ekologi, Sikap, Rank Spearman, U Mann Whitney

\section{PENDAHULUAN}

Dahuri (1991) menerangkan salah satu perhatian pada ekosistem mangrove yaitu ketidakjelasan kebijakan dan kurangnya koordinasi antara pemerintah pusat, propinsi dan kabupaten/kota, seringkali menjadi penyebab munculnya permasalahan tumpang tindih peruntukan areal di atas hutan mangrove. Perubahan paradigma pengelolaan hutan dari pola sentralisasi ke desentralisasi menambah daftar panjang permasalahan. Kerusakan hutan mangrove sebagai sabuk hijau (green belt) di pesisir DKI Jakarta sudah sangat memprihatinkan. Lebih dari lima puluh persen kerusakan telah terjadi yang banyak disebabkan oleh konversi hutan untuk peruntukan lain, pencemaran pantai oleh sampah dan industri, kurangnya kesadaran masyarakat akan pentingnya hutan mangrove sebagai penyangga kehidupan darat dan lautan, kurangnya usaha penataan dan penegakan hukum, belum adanya penataan ruang pesisir, pencemaran wilayah pesisir dan belum optimalnya pengelolaan perikanan serta kelautan.

Menurut Setyawan (2005) salah satu langkah untuk mengatasi kerusakan tersebut antara lain dilakukan upaya restorasi ekologi hutan mangrove. Restorasi ekologi hutan mangrove mendapat perhatian secara luas mengingat tingginya nilai sosial-ekonomi dan ekologi ekosistem ini. Restorasi ekologi hutan mangrove berpotensi besar menaikkan nilai sumber daya hayati mangrove, memberi mata pencaharian penduduk, mencegah kerusakan pantai, menjaga biodiversitas, produksi perikanan, dan lain-lain. Upaya restorasi ekologi hutan mangrove ini diperlukan sikap dan respon masyarakat sekitar. Sikap Positif akan membantu keberlangsungan dan kemajuan upaya tersebut. Akan tetapi ketika sikap masyarakat sekitar negatif maka upaya tersebut akan mengalami hambatan. Pandangan masyarakat terhadap upaya restorasi ekologi 


\section{Puspitasari, Lestari, Widiyanti, Hutan Mangrove,נ,}

hutan mangrove juga berhubungan dengan sikap masyarakat terhadap upaya tersebut. Upaya restorasi ekologi hutan mangrove di Kelurahan Marunda dikatakan berhasil apabila bermanfaat bagi masyarakat dan keluarganya.

Menurut Situs Jakarta.go.id (2010), Kelurahan Marunda merupakan salah satu kelurahan yang berada di tepian pantai utara DKI Jakarta yang telah mengalami kerusakan pantai akibat pembangunan perkotaan. Fokus penelitian akan dilaksanakan di kawasan Marunda Pulo yang lokasinya sesuai dengan konsep penelitian yaitu daerah pemukiman yang berada 400 meter dari pinggir pantai. Lokasi ini pula terdapat peralihan fungsi dari lahan yang seharusnya dijadikan tempat tumbuh dan berkembangnya hutan bakau menjadi pusat industri bagi kepentingan pihak tertentu. Penelitian ini akan mengkaji sikap masyarakat Marunda Pulo terhadap restorasi ekologi hutan mangrove di Kelurahan Marunda untuk mengetahui tingkat keberhasilan upaya yang diadakan oleh pemerintah daerah tersebut maupun para komunitas-komunitas yang terkait dengan kegiatan penanaman hutan mangrove. Penelitian ini selain mengkaji adakah hubungan yang signifikan antara sikap masyarakat maupun faktor-faktor pembentuk sikap dengan upaya restorasi ekologi hutan mangrove, juga akan mengkaji apakah ada perbedaan sikap masyarakat yang berada di kawasan Marunda Pulo yang pemukimannya berada 400 meter di pinggir pantai dengan masyarakat yang pemukimannya berada lebih dari 400 meter di pinggir pantai berdasarkan dampak ekonomi masyarakat. Upaya restorasi ekologi hutan mangrove ini dapat mengembalikan fungsi dari pantai bagi kehidupan manusia dengan kaitannya sikap masyarakat terhadap upaya tersebut.

\section{METODE PENELITIAN}

Metode dasar penelitian ini adalah dengan menggunakan metode deskriptif kuantitatif. Proses penelitian dilakukan dengan teknik survei. Metode penelitian survei dilakukan dengan mengumpulkan data melalui wawancara secara langsung dengan menggunakan kuisioner.

Pemilihan lokasi penelitian menggunakan metode purposive. Metode purposive yaitu ditentukan dengan sengaja berdasarkan pertimbangan dan kepentingan penelitian. Pemilihan Marunda Pulo berdasarkan atas pertimbangan peneliti yang memilih kawasan yang lokasi nya paling dekat dengan lokasi pinggir pantai yang terdapat hutan mangrove sebagai upaya restorasi ekologi hutan mangrove. 


\section{Jurnal Agritexts Volume 41 Nomer 2 Oktober 2017}

Populasi dalam penelitian ini adalah masyarakat Marunda Pulo yang bermukim 400 meter dari pinggir pantai dan masyarakat Marunda Pulo yang bermukim lebih dari 400 meter dari pinggir pantai. Sedangkan teknik pengambilan sampel dalam penelitian ini menggunakan teknik multistage random sampling. Menurut Nazir (2005) multistage random sampling merupakan teknik pengambilan sampel yang dilakukan secara berurutan dalam dua level tingkatan atau lebih. Penarikan sampel dilakukan secara acak.

Sumber data yang digunakan dalam penelitian ini adalah data primer dan sekunder. Teknik pengumpulan data dalam penelitian ini adalah dengan menggunakan teknik observasi, wawancara, dan dokumentasi. Data masyarakat yang diperoleh akan dianalisis menggunakan metode statistik non parametrik. Untuk mengetahui faktor pembentuk sikap masyarakat menggunakan metode analisis deskriptif, sedangkan sikap masyarakat diukur menggunakan kelas kategori (lebar interval), selanjutnya pengujian penelitian ini menggunakan korelasi rank spearman ( $r s$ ) untuk mengetahui hubungan faktor pembentuk sikap dengan sikap masyarakat, sedangkan untuk uji beda menggunakan uji $u$ mann whitney untuk membandingkan sikap masyarakat berdasarkan dampak ekonomi nya terhadap dampak restorasi ekologi. Berikut rumus hitung dari rank spearman (rs) dan uji u mann whitney.

$$
r_{s}=1-\frac{6 \sum_{i=1} d i^{2}}{\mathrm{~N}^{3}-\mathrm{N}}
$$

Keterangan :

$r_{s} \quad=$ koefisien korelasi rank spearman

$\mathrm{N} \quad=$ jumlah sampel masyarakat

di =selisih ranking antar variabel

$\mathrm{Z}=\frac{U-\frac{n_{1} n_{2}}{2}}{\sqrt{\left(\frac{n_{1} n_{2}}{N(N-1)}\right)\left(\frac{N^{2}-N}{12}-\text { jumla } h T\right)}} \ldots \ldots . .$.

\section{HASIL DAN PEMBAHASAN}

Kelurahan Marunda merupakan salah satu Kelurahan di Kecamatan Cilincing yang terletak antara $106^{\circ}-54^{\prime}-00^{\prime \prime}$ Bujur Timur dan 06 $-02^{\prime}-10^{\prime \prime} \quad$ Lintang Selatan. Kelurahan Marunda termasuk dalam bagian wilayah Dataran Alluvial yang memiliki kemiringan lereng datar hingga miring landai (0 - $15 \%)$, dengan ketinggian berkisar antara 0 $16 \mathrm{~m}$ di atas permukaan laut. Disamping itu dalam satuan ini terdapat bentuk darat (landform) dalam skala yang lebih lokal yaitu berupa dataran rawa, pematang pantai, dan delta dengan batuan penyusun utama berupa endapan alluvial terdiri dari fragmen lempung 
Puspitasari, Lestari, Widiyanti, Hutan Mangrove,נ,

hingga pasir kasar yang umumnya bersifat lepas mengandung pecahanpecahan cangkang serta sisa-sisa tumbuhan Marunda Pulo berbentuk segitiga yang dapat dikatakan pulau ini terbentuk dalam laguna. Terbentuk dari endapan sungai Marunda di muaranya. Pengendapan itu dipercepat oleh melambatnya aliran sungai dan dangkalnya laut pantai. (Kelurahan Marunda Dalam Angka, 2016)
Sikap Masyarakat terhadap Restorasi Ekologi Hutan Mangrove

Sikap masyarakat terhadap restorasi ekologi hutan mangrove adalahkesadaran individu yang menentukan kesiapan merespon yang sifatnya positif atau negatif terhadap objek atau situasi secara konsisten dalam upaya restorasi hutan mangrove.

Tabel 1. Distribusi Sikap Masyarakat Marunda Pulo terhadap Restorasi Ekologi Hutan Mangrove

\begin{tabular}{|c|c|c|c|c|c|c|c|}
\hline \multirow[t]{3}{*}{ Kategori } & \multirow[t]{3}{*}{ Skor } & \multicolumn{4}{|c|}{ Responden } & \multicolumn{2}{|c|}{ Total Responden } \\
\hline & & \multicolumn{2}{|c|}{ RT 001} & \multicolumn{2}{|c|}{ RT 002} & \multirow[b]{2}{*}{$\Sigma$} & \multirow[b]{2}{*}{$\%$} \\
\hline & & $\Sigma$ & $\%$ & $\Sigma$ & $\%$ & & \\
\hline Restorasi & Secara & & & & & & \\
\hline \multicolumn{8}{|l|}{ Keseluruhan } \\
\hline Sangat Tidak Setuju & $3,0-5,4$ & 4 & 6,45 & 16 & 26,88 & 20 & 33,33 \\
\hline Tidak Setuju & $5,5-7,9$ & 6 & 9,67 & 20 & 33,66 & 26 & 43,33 \\
\hline Netral & $8,0-10,4$ & 8 & 12,90 & 1 & 2,10 & 9 & 15,00 \\
\hline Setuju & $10,5-12,9$ & 4 & 6,45 & 1 & 1,88 & 5 & 8,33 \\
\hline Sangat Setuju & $13,0-15,0$ & 0 & 0,00 & 0 & 0,00 & 0 & 0,00 \\
\hline \multicolumn{8}{|l|}{ Upaya melestarikan hutan } \\
\hline \multicolumn{8}{|c|}{ mangrove Secara Keseluruhan } \\
\hline Sangat Tidak Setuju & $11,0-19,8$ & 0 & 0,00 & 0 & 0,00 & 0 & 0,00 \\
\hline Tidak Setuju & $19,9-28,7$ & 11 & 17,74 & 3 & 5,56 & 14 & 23,30 \\
\hline Netral & $28,8-37,6$ & 9 & 14,51 & 3 & 5,49 & 12 & 20,00 \\
\hline Setuju & $37,7-46,5$ & 18 & 29,03 & 4 & 7,67 & 22 & 36,70 \\
\hline Sangat Setuju & $46,6-55,0$ & 12 & 20,00 & 0 & 0,00 & 12 & 20,00 \\
\hline \multicolumn{8}{|l|}{ Arahan Pemulihan Secara } \\
\hline \multicolumn{8}{|l|}{ Keseluruhan } \\
\hline Sangat Tidak Setuju & $6,0-10,8$ & 4 & 6,45 & 1 & 1,85 & 5 & 8,30 \\
\hline Tidak Setuju & $10,9-15,7$ & 4 & 6,45 & 3 & 5,25 & 7 & 11,70 \\
\hline Netral & $15,8-20,6$ & 9 & 14,52 & 2 & 3,78 & 11 & 18,30 \\
\hline Setuju & $20,7-25,5$ & 21 & 33,87 & 4 & 7,83 & 25 & 41,70 \\
\hline Sangat Setuju & $25,6-30,0$ & 9 & 14,52 & 3 & 5,48 & 12 & 20,00 \\
\hline \multicolumn{8}{|c|}{ Dampak Restorasi Ekologi Secara } \\
\hline \multicolumn{8}{|l|}{ Keseluruhan } \\
\hline Sangat Tidak Setuju & 1 & 1 & 1,61 & 6 & 10,09 & 7 & 11,70 \\
\hline Tidak Setuju & 2 & 4 & 6,45 & 15 & 25,25 & 19 & 31,70 \\
\hline Netral & 3 & 12 & 19,35 & 1 & 2,35 & 13 & 21,70 \\
\hline Setuju & 4 & 11 & 17,74 & 4 & 7,26 & 15 & 25,00 \\
\hline Sangat Setuju & 5 & 6 & 10,00 & 0 & 0,00 & 6 & 10,00 \\
\hline Jumlah & & 31 & 50,00 & 29 & 50,00 & 60 & 100,00 \\
\hline
\end{tabular}

Sumber : Analisis Data Primer, 2017 


\section{Jurnal Agritexts Volume 41 Nomer 2 Oktober 2017}

Sikap Masyarakat terhadap Tujuan Restorasi Hutan Mangrove

Bahwa sikap masyarakat terhadap tujuan restorasi tersebut keseluruhan termasuk sikap masyarakat yang tidak setuju terhadap tujuan restorasi ekologi menunjukkan sebanyak 26 responden atau $43,33 \%$. Selama ini masyarakat yang tidak setuju dikarenakan masyarakat masih begitu awam dengan tujuan dari restorasi ekologi hutan mangrove apakah sudah sejalan dengan tujuan restorasi ekologi yaitu sebagai upaya untuk meningkatkan kesejahteraan masyarakat Marunda Pulo.

\section{Sikap Masyarakat terhadap Upaya Melestarikan Hutan Mangrove}

Bahwa upaya melestarikan hutan mangrove secara keseluruhan termasuk ke dalam kategori setuju untuk upaya melestarikan hutan mangrove sebanyak 22 responden atau $36,70 \%$. Upaya melestarikan hutan mangrove tersebut terdiri dari pelibatan masyarakat dalam penanaman tanaman mangrove dan pelibatan masyarakat dalam tata ruang wilayah pesisir. Sebagian besar masyarakat Marunda Pulo telah memiliki kesadaran untuk melestarikan hutan mangrove seperti diantaranya melakukan pemanfaatan dengan tetap menjaga kelestarian hutan mangrove yang memperhatikan kearifan lokal serta pengaturan tata ruang baik itu bangunan maupun vegetasi lain yang dapat mengganggu keangsungan hidup tanaman mangrove di Marunda Pulo. Namun sikap masyarakat yang sangat setuju dengan adanya upaya melestarikan hutan mangrove perlu didukung oleh pihak lain yang turut serta dalam pelestarian hutan mangrove tersebut, agar selain terjaga kawasan hutan mangrove di Marunda Pulo juga dapat berkelanjutan fungsi nya untuk masyarakat sekitar hutan mangrove.

\section{Sikap Masyarakat terhadap Arahan Pemulihan Kawasan Mangrove}

Bahwa arahan pemulihan kawasan secara keseluruhan termasuk sangat setuju dengan arahan pemulihan kawasan hutan mangrove sebanyak 36 responden atau $60 \%$. $\mathrm{Hal}$ tersebut dikarenakan dalam harmonisasi lingkungan sosial masyarakat telah ikut andil dalam pembentukan kelompok sosial dalam pelestarian lingkungan khususnya terkait dengan kawasan hutan mangrove. Peran instansi yang terkait berasal dari Dinas Kehutanan yang selama ini memebrikan dukungan kepada masyarakat untuk mengelola lingkungan nya sendiri dengan bantuan dari dinas tersebut. Pembinaan dan peningkatan kualitas habitat dengan meningkatkan jumlah dari tanaman mangrove yang diupayakan oleh masyarakat serta 


\section{Puspitasari, Lestari, Widiyanti, Hutan Mangrove,,,}

kelompok masyarakat lain dalan upaya perlindungan kawasan yang sudah mulai mengalami degradasi kawasan pantai. Peningkatan pemulihan kawasan hijau dengan cara reboisasi dengan tanaman lain yang dapat bermanfaat untuk meningkatkan daya dukung lingkungan. Rehabilitasi dan reklamasi yang telah diupayakan untuk melindungi hutan mangrove dan meminimalkan terjadinya abrasi air laut yang dapat memperkecil daratan.

\section{Sikap Masyarakat terhadap Dampak Restorasi Hutan Mangrove}

Bahwa dampak restorasi ekologi secara keseluruhan termasuk sangat setuju dengan dampak restorasi ekologi hutan mangrove sebanyak 38 responden atau 63,33 $\%$. Hal tersebut dikarenakan pada dampak sosial, masyarakat Marunda Pulo sangat setuju dan memiliki keinginan untuk dilibatkan secara penuh oleh pihak-pihak terkait dengan restorasi hutan mangrove ini, namun masyarakat memerlukan pendampingan khusus agar kegiatan yang mereka laksanakan tersebut tetap terarah dan sesuai dengan aturan-aturan yang telah ada dalam Upaya Restorasi Ekologi Hutan Mangrove. Kemudian pada dampak ekologi masyarakat dapat membantu mengembalikan kembali fungsi dari hutan mangrove sebagai habitat hewan-hewan laut serta dapat menjaga kelestarian alam sekitar, selain lingkungan terjaga dengan baik, kegiatan perekonomian masyarakat akibat terjaganya lingkungan habitat mangrove tersebut juga meningkat dengan baik. Dampak ekonomi terhadap restorasi ekologi hutan mangrove dapat menghidupkan kembali kekayaan flora maupun fauna yang dapat menjadi sumber penghasilan bagi masyarakat sekitar kawasan Marunda.

\section{Hubungan Antara Faktor-faktor Pembentuk Sikap dengan Sikap Masyarakat terhadap Restorasi Ekologi Hutan Mangrove di Kampung Marunda Pulo}

Penelitian ini dilakukan untuk mengetahui hubungan antara faktorfaktor pembentuk sikap masyarakat dengan sikap masyarakat Marunda Pulo terhadap restorasi ekologi hutan mangrove di Kelurahan Marunda. Berikut merupakan tabel 2. Analisis data hubungan antara faktor-faktor pembentuk sikap terhadap sikap masyarakat Marunda Pulo. 


\section{Jurnal Agritexts Volume 41 Nomer 2 Oktober 2017}

Tabel 2. Analisis Data Hubungan antara Faktor-Faktor Pembentuk Sikap terhadap Sikap Masyarakat Marunda Pulo

\begin{tabular}{|c|c|c|c|c|c|c|c|}
\hline \multirow[t]{2}{*}{ No } & \multirow{2}{*}{\multicolumn{2}{|c|}{$\begin{array}{c}\text { Faktor-faktor } \\
\text { Pembentuk Sikap }\end{array}$}} & \multicolumn{5}{|c|}{ Sikap Masyarakat } \\
\hline & & & Y1 & Y2 & Y3 & Y4 & Ytot \\
\hline \multirow[t]{4}{*}{1} & $\mathrm{X} 1$ & $R s$ &,- 060 &,- 079 & 201 & ,015 & ,027 \\
\hline & & t.hit & ,458 & 604 & 1,563 & 114 & 206 \\
\hline & & Sig. (2-tailed) & 649 & ,549 & 123 & 907 & 840 \\
\hline & & $\mathrm{N}$ & 60 & 60 & 60 & 60 & 60 \\
\hline \multirow[t]{4}{*}{2} & $\mathrm{X} 2$ & $R s$ &,- 097 &,- 092 &,- 050 &,- 185 &,- 164 \\
\hline & & t.hit & 206 & ,727 & 642 & 1,061 & 129 \\
\hline & & Sig. (2-tailed) & ,462 & ,486 & 705 & 157 & 211 \\
\hline & & $\mathrm{N}$ & 60 & 60 & 60 & 60 & 60 \\
\hline \multirow[t]{4}{*}{3} & $\mathrm{X} 3$ & $R s$ &,- 248 & ,059 & ,002 &,- 003 &,- 032 \\
\hline & & t.hit & 1,950 & ,450 & ,015 & ,023 & ,244 \\
\hline & & Sig. (2-tailed) & ,056 & ,656 & 987 & 984 & 809 \\
\hline & & $\mathrm{N}$ & 60 & 60 & 60 & 60 & 60 \\
\hline \multirow[t]{4}{*}{4} & $\mathrm{X} 4$ & Rs &,- 024 & ,053 &,- 198 &,- 109 &,- 121 \\
\hline & & t.hit & 183 & ,404 & 1,538 & ,835 & 928 \\
\hline & & Sig. (2-tailed) & ,854 & 686 & 129 & ,405 & 357 \\
\hline & & $\mathrm{N}$ & 60 & 60 & 60 & 60 & 60 \\
\hline \multirow[t]{4}{*}{5} & $x 5$ & $R s$ & ,040 &,$- 273^{*}$ &,- 203 &,- 017 &,$- 337^{* *}$ \\
\hline & & t.hit & ,305 & 2,161 & 1,579 & 129 & 2,726 \\
\hline & & Sig. (2-tailed) & ,762 & ,035 & 119 & , 898 & ,008 \\
\hline & & $\mathrm{N}$ & 60 & 60 & 60 & 60 & 60 \\
\hline \multirow[t]{4}{*}{6} & $x 6$ & Rs &,- 023 &,- 087 &,- 083 &,- 126 &,- 123 \\
\hline & & t.hit & 175 & 665 & ,634 & ,967 & 944 \\
\hline & & Sig. (2-tailed) & , 860 & ,506 & ,527 & ,336 & 347 \\
\hline & & $\mathrm{N}$ & 60 & 60 & 60 & 60 & 60 \\
\hline
\end{tabular}

Sumber : Analisis Data Primer, 2017

Hubungan antara Umur dengan Sikap Masyarakat terhadap Restorasi Ekologi Hutan Mangrove di Kampung Marunda Pulo

Bahwa nilai koefisien korelasi $\left(r_{s}\right)$ sebesar $0,027, \mathrm{p}$ value sebesar 0,840 , dengan $t_{\text {hitung }}$ sebesar $(0,206)$ dan $t_{\text {tabel }}$ sebesar $(2,008)$, sehingga dapat diketahui bahwa $t_{\text {hitung }}<t_{\text {tabel }}$ pada taraf signifikansi 95\% maka HO diterima dan H1 ditolak, yang artinya tidak terdapat hubungan yang signifikan antara umur dengan sikap masyarakat terhadap restorasi ekologi hutan mangrove. Hal ini menunjukkan bahwa perbedaan tingkat umur dan bertambahnya umur masyarakat tidak berhubungan dengan sikap masyarakat terhadap restorasi ekologi hutan mangrove.

Hubungan yang tidak signifikan serta koefisien korelasi yang positif antara umur dengan sikap masyarakat terhadap restorasi ekologi hutan mangrove menunjukkan bahwa sikap masyarakat tidak berhubungan dengan tingkat umur 


\section{Puspitasari, Lestari, Widiyanti, Hutan Mangrove,נ,}

masyarakat, bertambahnya umur masyarakat tidak berhubungan dengan baik maupun buruk sikap masyarakat terhadap restorasi ekologi hutan mangrove. hasil penelitian ini tidak sesuai dengan dengan pernyataan Huclock dalam Notoatmojo (2003) bahwa semakin cukup umur, tingkat kematangan dan kekuatan seseorang akan lebih matang dalam berfikir dan bekerja. Umur mempengaruhi daya tangkap dan pola pikir seseorang. Semakin bertambah umur akan semakin berkembang pula daya tangkap dan pola pikirnya, sehingga pengetahuan yang diperoleh semakin banyak.

Umur masyarakat baik yang produktif maupun non produktif berperan aktif dalam restorasi ekologi hutan mangrove serta mempunyai kesempatan yang sama. Biasanya masyarakat umur produktif akan cenderung mencoba suatu hal yang baru guna mengembangkan kegiatan dalam upaya restorasi ekologi hutan mangrove tersebut. sedangkan pada masyarakat usia non produktif tetap aktif pada kegiatan restorasi ekologi hutan mangrove. Hasil dari penelitian menunjukkan bahwa masyarakat di Marunda Pulo dalam kategori dewasa awal terhadap restorasi ekologi hutan mangrove cukup baik. Hal ini menerangkan bahwa masyarakat dengan kategori umur dewasa awal memiliki sikap yang cukup baik terhadap restorasi ekologi hutan mangrove meliputi tujuan restorasi, upaya pemeliharaan, arahan pemulihan serta dampak restorasi. Sikap yang baik terhadap restorasi ekologi hutan mangrove tidak terlepas berdasarkan informasi yang didapat masyarakat, sehingga menunjukkan bahwa umur masyarakat tidak berhubungan terhadap semangat dan kemauan mencari informasi terkait kehutanan seperti restorasi ekologi hutan mangrove.

\section{Hubungan antara Jenis Pekerjaan dengan Sikap Masyarakat terhadap Restorasi Ekologi Hutan Mangrove di Kampung Marunda Pulo}

Bahwa nilai koefisien korelasi $\left(r_{s}\right)$ sebesar 0,164, $\mathrm{p}$ value sebesar 0,211 , dengan $t_{\text {hitung }}$ sebesar $(0,129)$ dan $t_{\text {tabel }}$ sebesar $(2,008)$, sehingga dapat diketahui bahwa $t_{\text {hitung }}<t_{\text {tabel }}$ pada taraf signifikansi 95\% maka HO diterima dan H1 ditolak, yang artinya tidak terdapat hubungan yang signifikan antara jenis pekerjaan dengan sikap masyarakat terhadap restorasi ekologi hutan mangrove. Hal ini menunjukkan bahwa perbedaan jenis pekerjaan masyarakat tidak berhubungan dengan sikap masyarakat terhadap restorasi ekologi hutan mangrove.

$$
\text { Hubungan yang tidak }
$$
signifikan serta koefisien korelasi yang positif antara jenis pekerjaan dengan sikap masyarakat terhadap 


\section{Jurnal Agritexts Volume 41 Nomer 2 Oktober 2017}

restorasi ekologi hutan mangrove menunjukkan bahwa sikap masyarakat tidak berhubungan dengan jenis pekerjaan masyarakat, jenis pekerjaan masyarakat tidak berhubungan dengan baik maupun buruk sikap masyarakat terhadap restorasi ekologi hutan mangrove. hasil penelitian ini memiliki kesesuaian dengan pernyataan Thomas yang dikutip oleh Nursalam (2003) bahwa pekerjaan bukanlah sumber kesenangan, tetapi merupakan cara mencari nafkah, berulang dan banyak tantangan. Pekerjaan dalam arti luas adalah aktifitas utama yang dilakukan oleh manusia, dalam arti sempit istilah pekerjaan digunakan untuk suatu tugas / kerja yang menghasilkan uang bagi seseorang.

Hasil dari penelitian menunjukkan bahwa masyarakat di Marunda Pulo bekerja sebagai buruh. Hal ini menerangkan bahwa masyarakat dengan jenis pekerjaan tersebut belum tentu memiliki sikap yang cukup baik terhadap restorasi ekologi hutan mangrove meliputi tujuan restorasi, upaya pemeliharaan, arahan pemulihan serta dampak restorasi. Sikap yang baik terhadap restorasi ekologi hutan mangrove tidak ditentukan oleh jenis pekerjaan dari masyarakat. Hal tersebut dikarenakan tidak menutup kemungkinan masyarakat yang bekerja di jenis pekerjaan lain juga memiliki sikap yang baik terhadap restorasi ekologi hutan mangrove.

\section{Hubungan antara Pendidikan Formal dengan Sikap Masyarakat terhadap Restorasi Ekologi Hutan Mangrove di Kampung Marunda Pulo}

Bahwa nilai koefisien korelasi $\left(r_{s}\right)$ sebesar -0,032, p value sebesar 0,809 , dengan $t_{\text {hitung }}$ sebesar $(0,244)$ dan $t_{\text {tabel }}$ sebesar $(2,008)$, sehingga dapat diketahui bahwa $t_{\text {hitung }}<t_{\text {tabel }}$ pada taraf signifikansi 95\% maka HO diterima dan $\mathrm{H} 1$ ditolak, yang artinya tidak terdapat hubungan yang signifikan antara pendidikan formal dengan sikap masyarakat terhadap restorasi ekologi hutan mangrove. Hal ini menunjukkan bahwa perbedaan pendidikan formal masyarakat tidak berhubungan dengan sikap masyarakat terhadap restorasi ekologi hutan mangrove.

Hubungan yang tidak signifikan serta koefisien korelasi yang negatif antara pendidikan formal dengan sikap masyarakat terhadap restorasi ekologi hutan mangrove menunjukkan bahwa sikap masyarakat tidak berhubungan dengan tingkat pendidikan formal masyarakat. Hasil dari penelitian menunjukkan masyarakat Marunda Pulo memiliki tingkat pendidikan formal pada tingkatan SMA. Tingkat pendidikan tidak menjamin semakin baiknya sikap masyarakat terhadap 
restorasi ekologi hutan mangrove, tidak menutup kemungkinan masyarakat yang berada pada tingkatan pendidikan yang rendah maupun menengah memiliki sikap yang jauh lebih baik terhadap restorasi ekologi hutan mangrove daripada tingkat pendidikan yang lebih tinggi. Maka dari itu, tingkat pendidikan formal tidak menjamin semakin baik maupun buruknya sikap masyarakat terhadap restorasi ekologi hutan mangrove. Masyarakat Marunda Pulo yang memiliki tingkat pendidikan yang rendah lebih menjaga kelestarian hutan mangrove dikarenakan terkait dengan pendidikan masyarakat tersebut yang rendah yang menjadi alasan mereka menjaga kelestarian hutan mangrove untuk memanfaatkan hasil dari hutan mangrove tersebut. Mereka menyadari keberadaan hutan mangrove dapat berdampak pada keberlangsungan perekonomian mereka sehari-hari, maka mereka berupaya sebaik mungkin untuk tetap menjaga keutuhan hutan mangrove agar terus dapat diambil hasilnya. Sedangkan untuk masyarakat Marunda Pulo yang memiliki tingkat pendidikan tinggi lebih memilih untuk bekerja sesuai dengan riwayat pendidikannya dan cenderung memilih bekerja jauh dari sektor kehutanan. Hal tersebut menyebabkan masyarakat dengan tingkat pendidikan tinggi kurang peduli terhadap kelestarian hutan mangrove dikarenakan tidak merasakan memanfaatkan hutan tersebut.

\section{Hubungan antara Pendidikan Non Formal dengan Sikap Masyarakat terhadap Restorasi Ekologi Hutan Mangrove di Kampung Marunda Pulo}

Bahwa nilai koefisien korelasi $\left(r_{s}\right)$ sebesar $-0,121, \mathrm{p}$ value sebesar 0,357 , dengan $t_{\text {hitung }}$ sebesar $(0,928)$ dan $t_{\text {tabel }}$ sebesar $(2,008)$, sehingga dapat diketahui bahwa $t_{\text {hitung }}<t_{\text {tabel }}$ pada taraf signifikansi 95\% maka HO diterima dan H1 ditolak, yang artinya tidak terdapat hubungan yang signifikan antara pendidikan non formal dengan sikap masyarakat terhadap restorasi ekologi hutan mangrove. Hal ini menunjukkan bahwa perbedaan pendidikan non formal tidak berhubungan dengan sikap masyarakat terhadap restorasi ekologi hutan mangrove.

Hubungan yang tidak signifikan serta koefisien korelasi yang negatif antara pendidikan non formal dengan sikap masyarakat terhadap restorasi ekologi hutan mangrove dikarenakan di lapangan kondisi pendidikan non formal yang ada di lingkungan masyarakat masih sangat rendah. Penelitian ini menunjukkan penyuluhan dan arisan memiliki korelasi yang negatif terhadap sikap masyarakat. Masyarakat Marunda 


\section{Jurnal Agritexts Volume 41 Nomer 2 Oktober 2017}

Pulo belum mendapatkan informasi melalui penyuluhan kehutanan maupun arisan yang terkait dengan restorasi ekologi dari pihak terkait. Oleh karena itu, sikap masyarakat sulit terbentuk melalui pendidikan non formal yang selama ini belum didapatkan oleh masyarakat Marunda Pulo.

Hubungan antara Pengaruh Orang Lain Yang Dianggap penting dengan Sikap Masyarakat terhadap Restorasi Ekologi Hutan Mangrove di Kampung Marunda Pulo

Bahwa nilai koefisien korelasi $\left(r_{s}\right)$ sebesar $-0,337, \mathrm{p}$ value sebesar 0,008 , dengan $t_{\text {hitung }}$ sebesar $(2,276)$ dan $t_{\text {tabel }}$ sebesar $(2,008)$, sehingga dapat diketahui bahwa $t_{\text {hitung }}>t_{\text {tabel }}$ pada taraf signifikansi 95\% maka $\mathrm{HO}$ ditolak dan $\mathrm{H} 1$ diterima, yang artinya terdapat hubungan yang signifikan antara pengaruh orang lain yang dianggap penting dengan sikap masyarakat terhadap restorasi ekologi hutan mangrove. Hal ini menunjukkan bahwa perbedaan pengaruh orang lain yang dianggap penting masyarakat berhubungan dengan sikap masyarakat terhadap restorasi ekologi hutan mangrove.

Hubungan yang signifikan serta koefisien korelasi yang negatif antara pengaruh orang lain yang dianggap penting dengan sikap masyarakat terhadap restorasi ekologi hutan mangrove menunjukkan bahwa sikap masyarakat berhubungan namun selama ini pengaruhnya terhadap orang lain yang dianggap penting bagi masyarakat masih sedikit. Hasil penelitian menunjukkan bahwa pengaruh orang lain yang selama ini didapatkan oleh masyarakat hanya melalui pihak lurah, pihak Dinas Kehutanan, serta komunitas YMI (Yayasan mangrove Indonesia) serta KeMANGTEER (Komunitas Relawan Mangrove Indonesia). Namun hal tersebut masih sangat kurang dalam menunjang perkembangan dari pemahaman dan implementasi masyarakat dalam memahami restorasi ekologi hutan mangrove. Perlunya peranan yang aktif dari pihak yang lebih dekat dengan masyarakat seperti pihak RT dan pihak RW dalam mendampingi serta mengontrol jalannya restorasi ekologi hutan mangrove yang agar pelaksanaan nya dapat berjalan dengan baik sesuai yang dianjurkan oleh Pemerintah. Selain itu masyarakat Marunda Pulo memerlukan pendampingan khusus oleh pihak penyuluh khususnya kehutanan yang dapat memberikan arahan serta motivasi agar masyarakat dapat menerapkan restorasi ekologi hutan mangrove secara utuh dan berkelanjutan di lingkungan Marunda pulo. 
Hubungan antara Keterpaan Media Massa dengan Sikap Masyarakat terhadap Restorasi Ekologi Hutan Mangrove di Kampung Marunda Pulo

Bahwa nilai koefisien korelasi $\left(r_{s}\right)$ sebesar $-0,123, \mathrm{p}$ value sebesar 0,347, dengan $t_{\text {hitung sebesar }}$ $(0,944)$ dan $t_{\text {tabel }}$ sebesar $(2,008)$, sehingga dapat diketahui bahwa $t_{\text {hitung }}<t_{\text {tabel }}$ pada taraf signifikansi 95\% maka $\mathrm{HO}$ diterima dan $\mathrm{H} 1$ ditolak, yang artinya tidak terdapat hubungan yang signifikan antara keterpaan media massa dengan sikap masyarakat terhadap restorasi ekologi hutan mangrove. Hal ini menunjukkan bahwa perbedaan keterpaan media massa masyarakat tidak berhubungan dengan sikap masyarakat terhadap restorasi ekologi hutan mangrove.

Hubungan yang tidak signifikan serta koefisien korelasi yang negatif antara keterpaan media massa dengan sikap masyarakat terhadap restorasi ekologi hutan mangrove menunjukkan selama ini media massa yang dapat diakses oleh masyarakat Marunda Pulo tidak memberikan cukup informasi mengenai restorasi ekologi hutan mangrove, terkecuali masyarakat mencari tahu secara pribadi terkait informasi restorasi ekologi hutan mangrove tersebut. Hal tersebut terkait dengan kondisi daya dukung lingkungan di Marunda Pulo yang semakin kecil dikarenakan pengaruh kerusakan alam secara terusmenerus yang mampu menjadikan alasan bagi masyarakat untuk mengetahui lebih jelas mengenai penjelasan restorasi ekologi hutan mangrove. namun, keinginan masyarakat untuk mengakses informasi tersebut perlu adanya dukungan dari pihak lain yang senantiasa memberikan pengetahuan akan pentingnya mengakses informasi tersebut dikarenakan itu untuk kepentingan masyarakat Marunda Pulo, karena yang lebih merasakan dampak nya adalah masyarakat Marunda Pulo itu sendiri.

Perbedaan Dampak Ekonomi Antara Sikap Masyarakat Yang Lokasi Tempat Tinggalnya Berada 400 Meter Dari Pinggir Pantai Dengan Sikap Masyarakat Lokasi Tempat Tinggalnya Lebih Dari 400 Meter

Tabel 3. Analisis Perbedaan Dampak Ekonomi dengan Sikap Masyarakat

\begin{tabular}{ll}
\hline \hline \multicolumn{2}{l}{ Perbedaan Sikap Masyarakat terhadap Dampak } \\
Ekonomi \\
\hline Mann-Whitney U & 431,500 \\
Wilcoxon W & 809,500 \\
Z & $-2,217$ \\
Asymp. Sig. (2-tailed) & 0,000 \\
\hline \hline
\end{tabular}

Sumber : Analisis Data Primer, 2017

Perbedaan antara sikap masyarakat dapat menjadi alasan perbedaan pemahaman masyarakat serta moral masyarakat menjadi dasar sikap, sehingga berpengaruh 


\section{Jurnal Agritexts Volume 41 Nomer 2 Oktober 2017}

terhadap kesejahteraan masyarakat. Perbedaan sikap masyarakat yang tempat tinggalnya berada 400 meter dari pinggir pantai dengan masyarakat yang tempat tinggalnya berada lebih dari 400 meter dari pinggi pantai berdasarkan dampak ekonomi restorasi ekologi hutan mangrove. Analisis perbedaan sikap ini menggunakan uji beda $U$ Mann Whitney dengan SPSS IBM 22 for windows 7.

Terdapat perbedaan sikap yang signifikan terhadap dampak ekonomi berdasarkan jarak tempat tinggal antara masyarakat yang bertempat tinggal 400 meter di pinggi pantai dengan masyarakat yang bertempat tinggal lebih dari 400 meter dari pinggi pantai. dengan nilai Mann Whitney $U$ sebesar 431,500, dan Asymp. Sig. Sebesar 0,000 serta $Z_{\text {hitung sebesar -1,217. Maka }}$ $Z_{\text {hitung }}>Z_{\text {tabel }}$ yaitu $2,217>1,96$, sehingga $H_{0}$ ditolak dan $H_{1}$ diterima. Hal ini menunjukkan bahwa sikap masyarakat yang jarak tempat tinggal nya dekat ( 400 meter ) lebih baik dari masyarakat yang jarak tempat tinggal nya jauh ( $>400$ meter ).

Perbedaan sikap ini berarti bahwa masyarakat dalam menilai objek akan bergantung pada intensitas manfaat yang didapat masyarakat, masyarakat dengan tempat tinggal yang jauh dari lokasi hutan mangrove cenderung pasif dalam memanfaatkan hutan mangrove. Artinya manfaat yang didapat oleh masyarakat yang tempat tinggalnya jauh dari lokasi hutan mangrove lebih sedikit merasakan manfaat hutan mangrove. Hal tersebut dikarenakan memang tidak memanfaatkan hutan mangrove tersebut dengan alasan bekerja di sektor lain lebih menjanjikan. Sedangkan untuk masyarakat yang tempat tinggal nya dekat dengan lokasi hutan mangrove lebih melihat peluang bahwa hutan mangrove tersebut dapat memberikan manfaat jika dijaga serta dilestarikan dengan baik. Dikarenakan aspek manfaat tersebut yang membuat masyarakat dengan lokasi tempat tinggal dekat dengan lokasi hutan mangrove lebih cenderung memiliki sikap yang jauh lebih baik dengan penerimaan upaya restorasi hutan mangrove dibandingkan dengan masyarakat yang tempat tinggal nya lebih jauh dari lokasi hutan mangrove.

Upaya untuk dapat menyamakan sikap telah dilakukan, dengan memperluar informasi akan pentingnya melakukan restorasi hutan mangrove, meliputi kegiatan sosialisasi oleh pihak lurah, dinas kehutanan dan juga pihak komunitas pecinta hutan mangrove. Namun, masih sangat diperlukan penyuluhan secara berkala guna memberikan informasi secara rutin kepada masyarakat agar senantiasa melestarikan keutuhan hutan mangrove 


\section{Puspitasari, Lestari, Widiyanti, Hutan Mangrove,נ,}

demi terciptanya kesejahteraan bersama.

\section{KESIMPULAN DAN SARAN}

\section{Kesimpulan}

Berdasarkan hasil penelitian dan pembahasan, maka diperoleh kesimpulan sebagai berikut :

1. Sikap masyarakat terhadap tujuan restorasi yaitu sebanyak 26 responden $(43,33 \%)$ dalamkategori tidak setuju.

2. Sikap masyarakat terhadap upaya melestarikan hutan mangrove yaitu sebanyak 22 responden $(36,70 \%)$ dalam kategori setuju.

3. Sikap masyarakat terhadap arahan pemulihan hutan mangrove yaitu sebanyak 25 responden (41,70\%) dalam kategori setuju.

4. Sikap masyarakat terhadap dampak restorasi ekologi hutan mangrove yaitu sebanyak 19 responden (31,70\%) dalam kategori tidak setuju.

5. Terdapat hubungan yang signifikan antara sikap masyarakat terhadap restorasi ekologi hutan mangrove dengan pengaruh orang lain yang dianggap penting.

6. Tidak terdapat hubungan yang signifikan antara sikap masyarakat terhadap restorasi ekologi hutan mangrove dengan umur, jenis pekerjaan, pendidikan formal, pendidikan non formal, dan keterpaan terhadap media massa.
7. Terdapat perbedaan yang signifikanantara sikap masyarakat yang lokasi tempat tinggalnya berada 400 meter dari pinggir pantai dengan sikap masyarakat yang tempat tinggalnya lebih dari 400 meter dari pinggir pantai.

\section{Saran}

Berdasarkan hasil penelitian dan pembahasan, maka saran yang dapat diberikan adalah sebagai berikut:

1. Faktor-faktor pembentuk sikap yang tidak signifkan dengan sikap masyarakat, perlu adanya peningkatan terhadap faktor-faktor pembentuk sikap khususnya terkait orang-orang yang berperan sebagai fasilitator informasi dan media massa sebagai mediator informasi agar sikap masyarakat yang sudah sangat baik bertambah baik dan mampu dalam bertindak sesuai dengan sikap yang telah terbentuk dengan baik.

2. Perbedaan sikap antara masyarakat yang tinggal berada 400 meter dengan yang tinggal lebih dari 400 meter dari pinggir pantai terhadap dampak ekonomi, perlu adanya kerjasama antara masyarakat setempat, komunitas, kelurahan dan dinas kehutanan untuk mengupayakan agar baik masyarakat yang jauh maupun yang dekat dengan lokasi hutan mangrove dapat meningkatkan 


\section{Jurnal Agritexts Volume 41 Nomer 2 Oktober 2017}

pendapatannya melalui pemanfaatan hutan mangrove tersebut.

\section{DAFTAR PUSTAKA}

Ach. Muhib, Zainuri, Anang Takwanto dan Amir Syarifuddin. 2017. Konservasi Ekologi Hutan Mangrove di Kecamatan Mayangan Kota Probolinggo. Malang : Universitas Muhammadiyah Malang

Ahmadi. 1999. Psikologi Sosial. Melton Putra. Cetakan -1. Edisi Revisi. Jakarta.

Azwar, Saifuddin. (2005). Sikap Manusia: Teori dan Pengukurannya. Yogyakarta: Pustaka Pelajar.

Dahuri, R. 1991. Dinamic Interaction between Regional Development and Kutai National Park, East Kalimantan, Indonesia.Journal. Bogor : Bogor Agricultural University.

Effendi, S dan Tukiran. 2014. Metode Penelitian Survei. Jakarta: LP3ES.

Hurlock, E. B. 1999. Psikologi Perkembangan : Suatu Pendekatan Sepanjang Rentang Kehidupan (terjemahan Istiwidayanti \& Soedjarwo), Edisi 5. Jakarta : Penerbit Erlangga.

JG Kairo, F Dahdouh-Guebasm, dan N Koedam. 2001. Restoration and management of mangrove systems - a lesson for and from the East African region. Laboratory of General Botany and Nature Management, Mangrove Management Group. JournalBotany 67 : 383- 389.

Nazir, Moh. 2005. Metode Penelitian. Jakarta: Ghalia Indonesia

Notoatmodjo, Soekidjo. 2003. Pengembangan Sumber Daya Manusia. Jakarta : PT Rineka Cipta.

Nursalam. 2008. Konservasi Sumberdaya Ikan di Indonesia. Jakarta. Direktorat Konservasi dan Taman Nasional Laut, Direktorat Jenderal Kelautan, Pesisir dan Pulau-pulau Kecil, Departemen Kelautan dan Perikanan. 66 hal.

Peter Saenger. 1996. Mangrove restoration in Australia: a case study ofBrisbane International Airport. Australia : Southern Cross University.

Setyawan, AD dan Winarno, K. 2005. Permasalahan Konservasi Ekosistem Mangrove di Pesisir Kabupaten Rembang Jawa Tengah. Jurnal Biodiversitas. (2) : 159-163.

Siegel, Sidney. 1997. Statistik Non Parametrik. Jakarta : Bumi Aksara.

Singarimbun, Masri dan Sofian Effendi. 1995. Metode Pen- 
Puspitasari, Lestari, Widiyanti, Hutan Mangrove,

elitian Survei. Jakarta: Media Pratama.

Tarsoen Waryono. 2008. Restorasi Ekologi Hutan Mangrove ( Studi Kasus DKI Jakarta ).

Yuni Tri, Hewindati et al. 2013. Manfaat Pengelolaan Hutan Mangrove Suaka Margasatwa
Muara Angke terhadap Aspek Ekologis Kesehatan dan Ekonomi Masyarakat. Depok : Departemen Kesehatan Lingkungan Fakultas Kesehatan Masyarakat Universitas Indonesia. 